\begin{tabular}{c|c|c}
\hline \hline Vol. 247: 225-235, 2003 & MARINE ECOLOGY PROGRESS SERIES \\
Mar Ecol Prog Ser & Published February 4 \\
\hline
\end{tabular}

\title{
Patterns in fish assemblages 25 years after major seagrass loss
}

\author{
M. A. Vanderklift ${ }^{1, *}$, C. A. Jacoby ${ }^{2,3}$ \\ ${ }^{1}$ Centre for Ecosystem Management, Edith Cowan University, 100 Joondalup Drive, Joondalup, Western Australia 6027, \\ Australia \\ ${ }^{2}$ CSIRO Division of Marine Research, PO Box 20, North Beach, Western Australia 6020, Australia \\ ${ }^{3}$ Present address: Department of Fisheries and Aquatic Sciences, University of Florida, 7922 NW 71 st Street, Gainesville, \\ Florida 32653-3071, USA
}

\begin{abstract}
Inferences about the effects of habitat loss may be derived from comparisons of different places when pre-impact data are unavailable. We compared the fish faunas of sandy substrata off beaches with and without seagrass in Cockburn Sound (Western Australia), a bay where $>3000$ ha of seagrass was lost from the 1950s to the 1970s, and for which there are no pre-impact data. Numbers of species and individuals varied considerably in space and time, and this variation obscured patterns that might have been associated with the presence or absence of seagrass. Multivariate tests indicated some significant differences in species composition between beaches with and without seagrass; however, patterns among species were complex. Catches were strongly influenced by depth and the quantity of drifting vegetation. In general, fewer species were captured at shallower beaches. Hauls with a lot of drift captured more species, more individuals and higher biomasses of fishes that eat invertebrates and are associated with plants. When widespread seagrass loss occurs, resultant decreases in the supply of drift are likely to negatively affect densities of some fauna. We can make no firm conclusions about the effects of seagrass loss in Cockburn Sound, but suggest that declines in the production of drift have caused changes in fish assemblages.
\end{abstract}

KEY WORDS: Australia $\cdot$ Cockburn Sound $\cdot$ Drift $\cdot$ Guilds $\cdot$ Inference $\cdot$ Spatial subsidy

Resale or republication not permitted without written consent of the publisher

\section{INTRODUCTION}

Habitat loss is one of the main causes of changes in the species composition of ecological communities (Suchanek 1994, Gray 1997). Extensive losses of seagrass habitat have occurred in coastal marine ecosystems around the world in recent decades (Shepard et al. 1989, Short \& Wyllie-Echeverria 1996). In Australia, one of the most severe cases of seagrass dieback occurred in Cockburn Sound, a sheltered bay in Western Australia, where seagrass cover declined from 4200 ha in 1954 to 900 ha in 1978 (Cambridge \& McComb 1984). Relatively little is known about how these changes have affected fauna. Characterization of pre-impact fauna assemblages is difficult, because no quantitative surveys of the fauna of the nearshore habitats were

*Email: matvdk@cyllene.uwa.edu.au done before 1972 (Dybdahl 1979, Scott et al. 1986). By 1972 most of the seagrass loss had already occurred (Cambridge \& McComb 1984, Kendrick et al. 2002).

Potential direct and indirect effects of seagrass loss are numerous (Bellan-Santini \& Picard 1984, Jenkins et al. 1997). Direct effects include loss of fauna that eat seagrass or rely on seagrass for shelter (Edgar \& Shaw 1995). Indirect effects are likely to be more complex. For example, Heck et al. (1995) suggested that there would be major effects of seagrass loss on predators of seagrass-associated fauna. Farther afield, fauna in adjacent habitats may be affected by loss of trophic 'subsidy' (sensu Polis et al. 1997) provided by seagrass detritus (Asmus \& Asmus 2000).

These potential effects remain largely untested. When pre-impact data are scarce (as for Cockburn 
Sound), conventional methods for testing predictions, such as comparing pre-impact and post-impact conditions, may be difficult to apply. Manipulative experiments, which could be used to test predictions, are difficult to perform at a meaningful scale, and might also be socially unacceptable (Nagelkerken et al. 2001). Alternative methods for gaining insights into the effects of seagrass loss are therefore needed. One alternative may be historical reconstruction (Jackson 2001). Another approach is to draw inferences based on comparisons of different places (see for example the approach used by Estes et al. 1978). Comparing places with seagrass to places where seagrass has been lost should yield inferences about the types of species likely to be deleteriously affected by seagrass lossboth directly and indirectly. In the same way, comparisons of adjacent habitats may yield inferences about the effects of seagrass loss farther afield. For example, comparing habitats adjacent to existing seagrass beds with similar habitats adjacent to areas where seagrass has been lost might yield insights into possible indirect effects on the fauna. Such comparisons are most useful when set in a hypothesis-testing framework. For example, sandy beaches where offshore seagrass beds

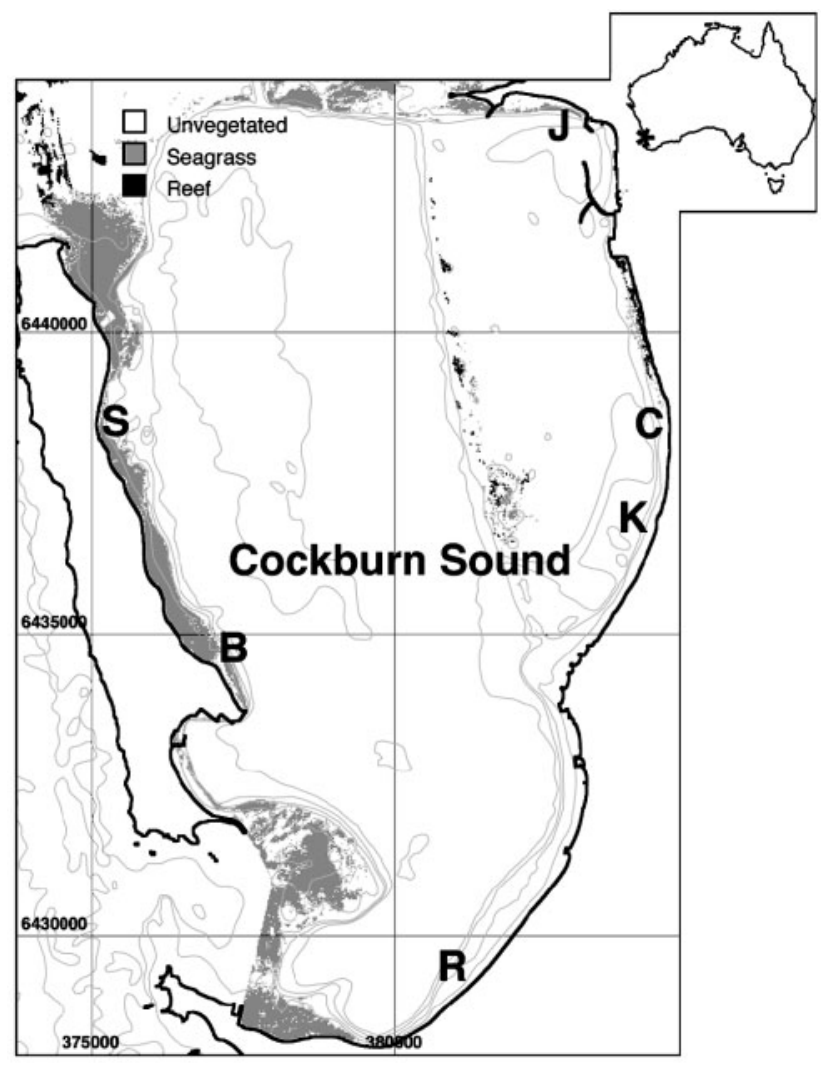

Fig. 1. Map of study area showing seagrass distribution and location of Cockburn Sound (*). Beaches with seagrass: $\mathrm{B}=$ Buchanan, $\mathrm{J}=$ Jervoise, $\mathrm{S}=$ Sulphur. Beaches without seagrass: $\mathrm{C}=$ Challenger, $\mathrm{K}=$ Kwinana, $\mathrm{R}=$ Rockingham have declined may be expected to receive less drift or be subject to greater wave energy, and so support different fish assemblages. The hypothesis that fish assemblages are different can be tested, although the reason(s) why might not be clearly identified.

We tested hypotheses about spatial patterns in fish assemblages related to seagrass distribution in Cockburn Sound approximately 25 yr after most of the seagrass loss had occurred. We compared fish assemblages captured over sandy substrata immediately off sandy beaches and inshore of seagrass beds with fish assemblages from the same habitat at localities where seagrass was lost by the early 1970s. If loss of seagrass causes predictable changes in fish assemblages of adjacent sandy habitats, we hypothesized that these 2 sets of samples would be different. We also sought to explore whether variation among catches could be related to differences in depth of water and the amount of drifting vegetation.

\section{MATERIALS AND METHODS}

Data collection. We studied 6 beaches in Cockburn Sound: 3 with seagrass beds growing immediately offshore and 3 with no extensive seagrass beds within at least $2 \mathrm{~km}$ (Fig. 1). Although we studied nearshore, sandy substrata at all beaches, for simplicity we refer to beaches with and without adjacent seagrass as being different 'habitats'.

Because little seagrass remains in Cockburn Sound (Fig. 1), we were forced to select beaches that varied in depth and aspect. Two of the beaches with seagrass (Buchanan and Sulphur) were on the western shore of Cockburn Sound with extensive beds of Posidonia spp. immediately offshore. The third beach with seagrass (Jervoise) faced south and had a small bed of Posidonia spp. immediately offshore and extending to the west (Fig. 1). Beaches without seagrass (Challenger, Kwinana and Rockingham) varied less: all were westfacing beaches where little or no seagrass has existed since before 1972 (Cambridge \& McComb 1984, Kendrick et al. 2002).

We sampled during two 6 wk time periods, one in May-June and one in October-November of 1995. Each time period was divided into two $3 \mathrm{wk}$ 'blocks'. Each beach was sampled once within each block. The sampling dates within each block were randomized, although some restrictions were applied to ensure temporal interspersion. The 2 westernmost beaches had to be sampled on the same day because of the extra travel time required. On each sampling occasion, 4 replicate seine hauls were taken. Replicate hauls were generally taken in a sequence along the beach, but they were separated by varying distances. 
A $40 \mathrm{~m}$ long beach seine was used because it captured a broad section of the fish assemblage (Vanderklift et al. 1998). It had a $10 \mathrm{~m}$ center bunt of $6 \mathrm{~mm}$ stretched mesh, with $15 \mathrm{~m}$ of $25 \mathrm{~mm}$ stretched mesh on either side. The seine was $3 \mathrm{~m}$ deep and had bridles, $25 \mathrm{~m}$ hauling lines at each end, lead weights attached to the bottom line, and plastic floats attached to the top line. Using an inflatable dingy powered by an outboard motor, we set the net $25 \mathrm{~m}$ offshore and parallel to the beach. It was hauled directly onto the beach, thus sweeping a maximum area of approximately $1000 \mathrm{~m}^{2}$, although actual area swept was slightly less due to curvature of the net as it was hauled onto the beach.

Fish were chilled during transport and then refrigerated or frozen. In the laboratory, the number of individuals and biomass ( $g$ wet $w t$ ) of each species was recorded. Several invertebrate species were captured, but because the net would not have sampled the smaller invertebrate species efficiently, only large portunid crabs, Portunus pelagicus and Ovalipes australiensis, and cuttlefish Sepia plangon were included in analyses.

Because variations in environmental features can affect catches of fish, we estimated depth and amount of drifting vegetation (drift) for each haul. Because these features varied among beaches and with time, we tested for corresponding patterns in fish assemblages that might obscure patterns related to our predefined habitats. Estimates for each haul were made as follows: (1) depth, estimated to the nearest $0.5 \mathrm{~m}$ just beyond the seine; and (2) drift, the quantity of drifting seagrass and macroalgae retained in each haul was estimated on an ordinal scale of 0 to 4 ( 0 for none and 4 for large quantities).

Data analysis. Analyses investigated patterns at the assemblage level (i.e. patterns in the identities, densities and biomasses of all species), focusing on patterns related to presence or absence of offshore seagrass beds. We conducted analyses including all species and also separately for 5 feeding guilds (modified from Ayvazian \& Hyndes 1995), because not all species were expected to show patterns associated with the presence or absence of seagrass. The feeding guilds were: sand-associated invertevores (i.e. invertevores living mainly on or just above the surface of the sand), plant-associated invertevores (i.e. invertevores generally associated with seagrass or algae), omnivores, zooplanktivores and piscivores.

For each of the data sets, 3 types of analyses were used to characterize patterns in assemblages. The number of species, the total number of individuals and total biomass were analyzed using analysis of variance (ANOVA). The statistical techniques of non-parametric multivariate analysis of variance (NPMANOVA) and ordination were used to test for multivariate patterns in the distributions. Variations in catches associated with different depths and quantities of drift were analyzed by multiple regression.

Prior to ANOVAs, data were tested for homoscedasticity using Cochran's test. If data were heteroscedastic, they were transformed. If the transformed data remained heteroscedastic, ANOVAs were conducted on the untransformed data, as ANOVA is robust to heteroscedasticity when data are balanced (Zar 1996). The full ANOVA model included the factors habitat (fixed), beach (random, nested within habitat), season (fixed) and block (random, nested within season). This model did not allow construction of an exact F-ratio for the factors of habitat or season. Because we were particularly interested in differences between habitats, and the block factor held no particular interest beyond estimating short-term variability, data from the 2 blocks were pooled when factors including this term were not significant at $\mathrm{p} \geq 0.25$. Pooling yielded a single set of 8 replicate hauls per beach within each season.

NPMANOVA (Anderson 2001, McArdle \& Anderson 2001) was used to test for differences in species compositions among our predefined sets of samples. NPMANOVA is analogous to ANOVA; the significance of the $F$-ratio is determined by permutation. We tested for the significance of differences between habitats and among beaches separately for each block of time. The analyses were based on Bray \& Curtis dissimilarities calculated using untransformed biomass data (biomass data were preferred because they were less influenced by dominant species). The method used was permutation of the residuals (Anderson \& Legendre 1999).

Ordinations were performed using semi-strong, hybrid multidimensional scaling (Belbin 1991). The ordinations were based on Bray \& Curtis dissimilarities calculated from log-transformed numbers of individuals (these data gave lower stresses than biomass data). Data were first pooled for each block. Ordinal regression was used for dissimilarity values above 0 to make the ordination essentially non-metric.

\section{RESULTS}

\section{Numbers of species}

Seine hauls from the 6 sites over 2 seasons yielded 55 species of fishes from 34 families and 3 species of large invertebrates (full species list in Vanderklift 1996). Piscivores were uncommon (8 individuals captured during the study) and were therefore not analyzed. The numbers of species in the other groups 
Table 1. Results of ANOVA on numbers of species. No exact F-test was possible for habitat, season, or the habitat $\times$ season interaction. Bold type indicates terms for which $\mathrm{p}<0.05$

\begin{tabular}{|c|c|c|c|c|c|c|c|c|c|c|c|c|c|c|c|}
\hline \multirow{4}{*}{$\begin{array}{l}\text { Guild } \\
\text { Transformation: } \\
\text { Cochran's test: }\end{array}$} & \multicolumn{3}{|c|}{ All species } & \multirow{3}{*}{\multicolumn{3}{|c|}{$\begin{array}{c}\text { Sand-associated } \\
\text { invertevores } \\
x^{0.5} \\
\mathrm{p}<0.05\end{array}$}} & \multirow{3}{*}{\multicolumn{3}{|c|}{$\begin{array}{c}\text { Plant-associated } \\
\text { invertevores } \\
x^{0.5} \\
p<0.05\end{array}$}} & \multirow{3}{*}{\multicolumn{3}{|c|}{$\begin{array}{l}\text { Omnivores } \\
\qquad \begin{array}{c}x^{0.5} \\
p<0.05\end{array}\end{array}$}} & \multirow{3}{*}{\multicolumn{3}{|c|}{$\begin{array}{c}\text { Zooplanktivores } \\
\qquad \begin{array}{c}\text { None } \\
\text { p }>0.05\end{array}\end{array}$}} \\
\hline & \multirow{2}{*}{\multicolumn{3}{|c|}{$\begin{array}{c}\text { None } \\
p>0.05\end{array}$}} & & & & & & & & & & & & \\
\hline & & & & & & & & & & & & & & & \\
\hline & MS & $F$ & $\mathrm{p}$ & MS & $F$ & $\mathrm{p}$ & MS & $F$ & $\mathrm{p}$ & MS & $F$ & $\mathrm{p}$ & MS & $F$ & $\mathrm{p}$ \\
\hline Habitat & 24.0 & & & 0.76 & & & 9.2 & & & 0.62 & & & 7.0 & & \\
\hline Beach (Habitat) & 22.6 & 4.8 & 0.029 & 1.3 & 1.6 & 0.251 & 2.7 & 3.7 & 0.053 & 1.9 & 4.1 & 0.041 & 4.4 & 5.8 & 0.017 \\
\hline Season & 12.0 & & & 0.62 & & & 0.04 & & & 1.1 & & & 7.0 & & \\
\hline Block (Season) & 9.3 & 1.9 & 0.204 & 5.7 & 7.4 & 0.015 & 0.18 & 0.25 & 0.783 & 0.04 & 0.08 & 0.922 & 0.94 & 1.2 & 0.341 \\
\hline Habitat $\times$ Season & 0.4 & & & 0.11 & & & 0.14 & & & 0.47 & & & 0.17 & & \\
\hline Habitat × Block (Season) & 0.37 & 0.07 & 0.929 & 0.90 & 1.2 & 0.359 & 0.15 & 0.21 & 0.812 & 0.06 & 0.13 & 0.883 & 1.3 & 1.7 & 0.247 \\
\hline Beach $($ Habitat $) \times$ Season & 12.5 & 2.6 & 0.114 & 0.22 & 0.29 & 0.876 & 0.28 & 0.39 & 0.809 & 0.39 & 0.87 & 0.521 & 1.4 & 1.9 & 0.196 \\
\hline $\begin{array}{r}\text { Beach (Habitat) } \times \text { Block } \\
(\text { Season) }\end{array}$ & 4.7 & 1.4 & 0.202 & 0.77 & 2.9 & 0.008 & 0.72 & 3.5 & 0.002 & 0.45 & 1.9 & 0.080 & 0.76 & 1.0 & 0.427 \\
\hline Residual & 3.3 & & & 0.27 & & & 0.20 & & & 0.24 & & & 0.74 & & \\
\hline
\end{tabular}
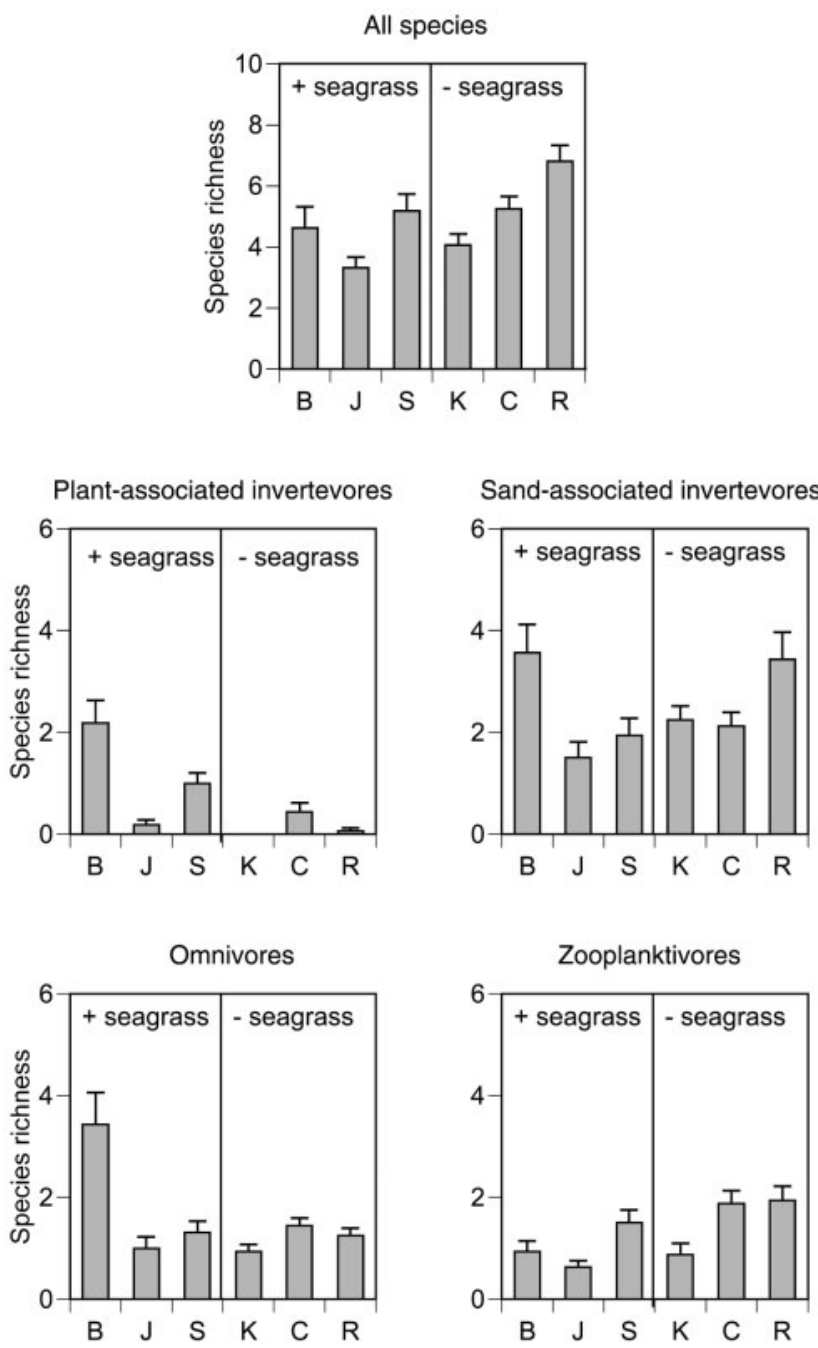

Fig. 2. Mean numbers of species $(+\mathrm{SE}, \mathrm{n}=16)$ for all species and each of the feeding guilds at each beach within each habitat. See Fig. 1 for beach abbreviations showed varying patterns (Table 1). Among-beach spatial variation and between-block temporal variation were generally important: numbers of sand- and plantassociated invertevore species varied significantly among times and places of sampling, but not according to any consistent pattern (note the significant interactions at the lowest level of analysis). The total number of species and numbers of omnivore and zooplanktivore species varied significantly among beaches within each habitat. Generally, greater numbers of species in these groups were caught at Buchanan and Sulphur (beaches with seagrass) and Rockingham and Challenger (beaches without seagrass) (Fig. 2).

\section{NPMANOVA}

Beach identity was an important source of variation in species composition (Table 2). At almost all times of sampling, there were significant differences in species composition among beaches for all species, sand- and plant-associated invertevores (Table 2). The species compositions of omnivores and zooplanktivores were less variable. Differences between habitats were present for all species, sand-associated invertevores, plant-associated invertevores and omnivores, but not consistently for all times of sampling (Table 2). Differences between habitats in the species composition of zooplanktivores also approached significance for one time of sampling (Table 2).

\section{Ordination}

Ordinations did not yield patterns with clear separation of samples according to the presence or absence 
of seagrass (Fig. 3). However, samples taken off beaches with seagrass tended to be on the edge of the ordination plots, suggesting that their species compositions were different from samples taken off beaches without seagrass (Fig. 3). Samples from Buchanan, and to a lesser extent Sulphur, also grouped separately from other samples, reflecting among-beach differences in species composition. This trend was most evident in the ordinations derived from all species and sand-associated invertevores (Fig. 3a,c). Stress values for ordinations were relatively high (range 0.17 to 0.24 ), indicating that patterns of association among samples were generally not well represented in a 2-dimensional plot. We generated 3-dimensional ordinations, which resulted in lower stresses but did not yield clearer patterns (for simplicity of presentation we show the results of the 2-dimensional ordinations only).

(a) All species

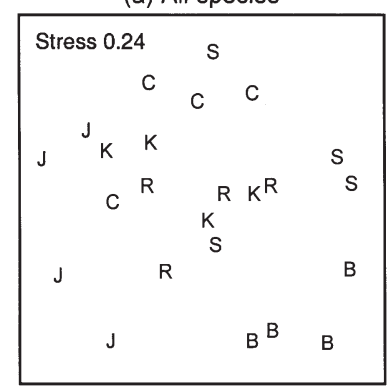

(b) Sand-associated invertevores

(c) Plant-associated invertevores

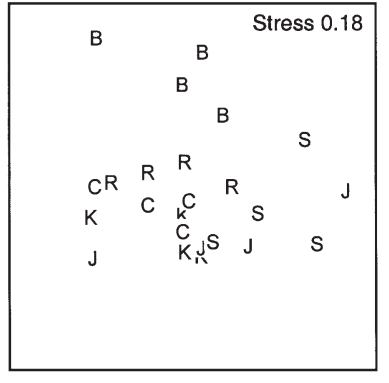

(d) Omnivores

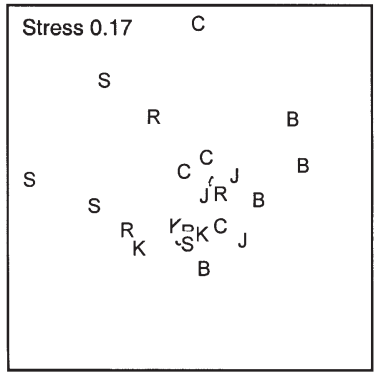

Fig. 3. Two-dimensional semi-strong hybrid multidimensional scaling ordinations derived from log-transformed numbers of individuals pooled across replicates. See Fig. 1. for beach abbreviations

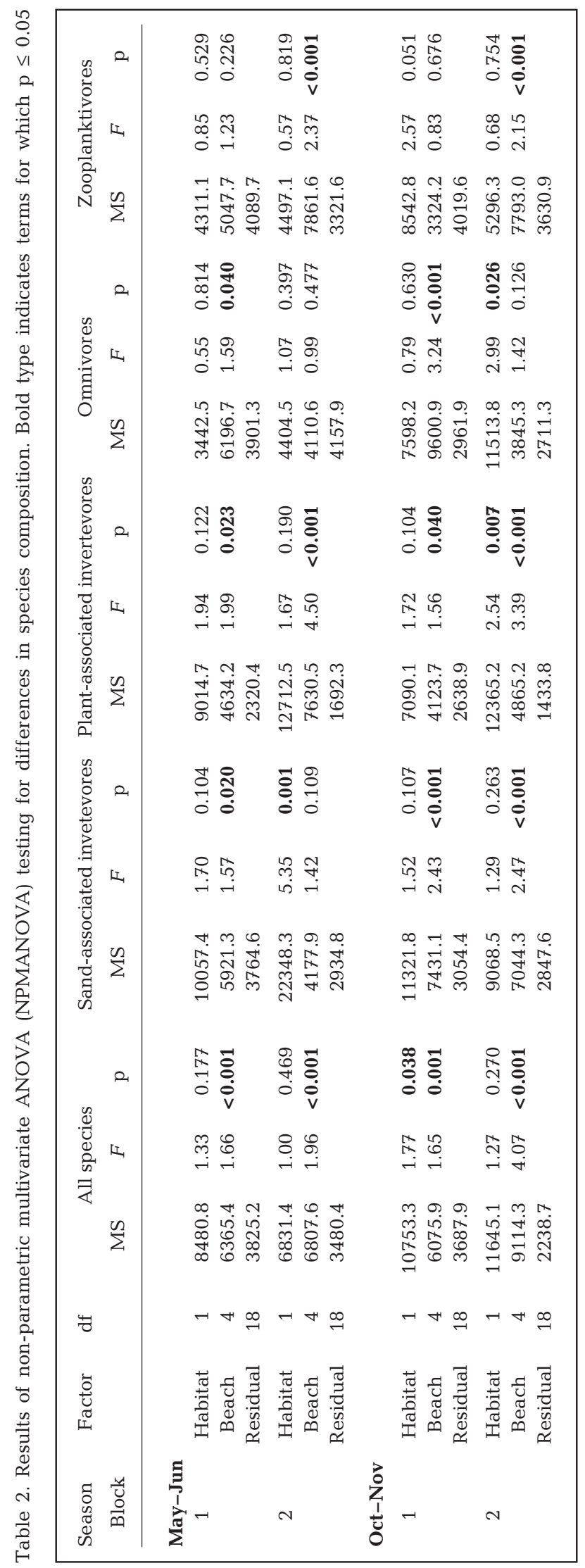


Table 3. Numbers of individuals, biomasses and proportions of total for (a) each of the feeding guilds and (b) species for which $>50$ individuals were captured during the study

\begin{tabular}{|c|c|c|c|c|c|c|c|}
\hline (a) Feeding guild & $\begin{array}{l}\text { Number of } \\
\text { species }\end{array}$ & $\begin{array}{l}\text { Number of } \\
\text { individuals } \\
\text { (+ seagrass) }\end{array}$ & $\begin{array}{l}\text { Number of } \\
\text { individuals } \\
\text { (- seagrass) }\end{array}$ & $\begin{array}{c}\text { Proportion of } \\
\text { total individuals } \\
(\%)\end{array}$ & $\begin{array}{c}\text { Biomass } \\
\text { (+ seagrass) }\end{array}$ & $\begin{array}{c}\text { Biomass } \\
(- \text { seagrass })\end{array}$ & $\begin{array}{c}\text { Proportion of } \\
\text { total biomass } \\
(\%)\end{array}$ \\
\hline Zooplanktivores & 5 & 9876 & 51824 & 89.4 & 8752.9 & 68227.3 & 43.4 \\
\hline $\begin{array}{l}\text { Sand-associated } \\
\text { invertevores }\end{array}$ & 18 & 524 & 4560 & 7.3 & 19766.0 & 45544.5 & 36.9 \\
\hline Omnivores & 14 & 1460 & 595 & 2.9 & 22253.1 & 8669.9 & 17.5 \\
\hline $\begin{array}{l}\text { Plant-associated } \\
\text { invertevores }\end{array}$ & 18 & 145 & 20 & 0.2 & 3237.5 & 471.1 & 2.1 \\
\hline Piscivores & 3 & 3 & 5 & 0.1 & 250.3 & 19.1 & 0.2 \\
\hline Total & 58 & 12008 & 57004 & & & & \\
\hline (b) Species & $\begin{array}{l}\text { Feeding } \\
\text { guild }\end{array}$ & $\begin{array}{l}\text { Number of } \\
\text { individuals } \\
\text { (+ seagrass) }\end{array}$ & $\begin{array}{l}\text { Number of } \\
\text { individuals } \\
\text { (- seagrass) }\end{array}$ & $\begin{array}{c}\text { Proportion of } \\
\text { total individuals } \\
(\%)\end{array}$ & $\begin{array}{c}\text { Biomass } \\
(+ \text { seagrass })\end{array}$ & $\begin{array}{c}\text { Biomass } \\
(- \text { seagrass })\end{array}$ & $\begin{array}{c}\text { Proportion of } \\
\text { total biomass } \\
(\%)\end{array}$ \\
\hline Hyperlophus vittatus & Zooplanktivore & 4352 & 32563 & 53.5 & 630.1 & 11056.5 & 6.6 \\
\hline Spratelloides robustus & Zooplanktivore & 1502 & 9075 & 15.3 & 3536.4 & 18840.7 & 12.6 \\
\hline $\begin{array}{l}\text { Leptatherina } \\
\text { presbyteroides }\end{array}$ & Zooplanktivore & 3921 & 4674 & 12.5 & 4051.3 & 5434.5 & 5.3 \\
\hline Atherinomorus ogilbyi & Zooplanktivore & 101 & 5442 & 8.0 & 534.9 & 32549.1 & 18.7 \\
\hline Sillago vittata & $\begin{array}{c}\text { Sand-associated } \\
\text { invertevore }\end{array}$ & 26 & 4295 & 6.3 & 69.2 & 39569.9 & 22.4 \\
\hline Aldrichetta forsteri & Omnivore & 1271 & 544 & 2.6 & 17479.3 & 7137.6 & 13.9 \\
\hline Ammotretis elongatus & $\begin{array}{l}\text { Sand-associated } \\
\text { invertevore }\end{array}$ & 130 & 77 & 0.3 & 257.1 & 355.9 & 0.3 \\
\hline Lesueurina sp. & $\begin{array}{l}\text { Sand-associated } \\
\text { invertevore }\end{array}$ & 73 & 93 & 0.2 & 62.4 & 101.4 & 0.1 \\
\hline Sillago schomburgkii & $\begin{array}{l}\text { Sand-associated } \\
\text { invertevore }\end{array}$ & 120 & 40 & 0.2 & 13614.1 & 4832.4 & 10.4 \\
\hline $\begin{array}{l}\text { Torguigener } \\
\quad \text { pleurogramma }\end{array}$ & Omnivore & 66 & 34 & 0.1 & 1023.4 & 789.8 & 1.0 \\
\hline Engraulis australis & Zooplanktivore & 0 & 70 & 0.1 & 0.0 & 346.5 & 0.2 \\
\hline Sillago burrus & $\begin{array}{l}\text { Sand-associated } \\
\text { invertevore }\end{array}$ & 49 & 13 & 0.1 & 284.0 & 49.1 & 0.2 \\
\hline Sillaginodes punctata & $\begin{array}{c}\text { Sand-associated } \\
\text { invertevore }\end{array}$ & 58 & 1 & 0.1 & 161.8 & 36.3 & 0.1 \\
\hline Favonigobius lateralis & $\begin{array}{l}\text { Sand-associated } \\
\text { invertevore }\end{array}$ & 30 & 21 & 0.1 & 18.6 & 29.3 & 0.1 \\
\hline
\end{tabular}

\section{Number of individuals}

A total of 69012 fish were captured during this study. Numbers were dominated by 5 species of schooling zooplanktivores, with $89 \%$ of individuals belonging to these species (Table 3). Sand-associated invertevores and omnivores were also captured in high numbers (Table 3). Each of these guilds was numerically dominated by single species: Hyperlophus vittatus comprised a large proportion of zooplanktivores (60\%), Sillago vittata was the most abundant sand-associated invertevore (85\%) and Aldrichetta forsteri was the most abundant omnivore (88\%).

Among-beach spatial variation and between-block temporal variation dominated analyses of number of individuals, with significant interactions for all groups (Table 4). Because of the significant interaction terms, patterns related to the presence of seagrass could not be tested, although the mean number of all individuals was greater at beaches with no adjacent seagrass $\left(\right.$ mean $=1187.6$ ind . haul $^{-1}$ ) than at beaches with adjacent seagrass $\left(\right.$ mean $=250.2$ ind . haul ${ }^{-1}$ ). Most of this difference was due to higher densities of 4 species at beaches without seagrass (the clupeids Hyperlophus vittatus and Spratelloides robustus, the atherinid Leptatherina presbyteroides and the sillaginid Sillago vittata: see Table 3). Unlike the trends in the numbers of species, beach identity was not an important source of variation in numbers of individuals. These results indicate that any broad-scale spatial 
Table 4. Results of ANOVA on number of individuals of all species combined and each of the feeding guilds. No exact $F$-test was possible for habitat, season, or the habitat $\times$ season interaction. Bold type indicates terms for which $\mathrm{p}<0.05$

\begin{tabular}{|c|c|c|c|c|c|c|c|c|c|c|c|c|c|c|c|}
\hline Guild & \multirow{3}{*}{\multicolumn{3}{|c|}{$\begin{array}{l}\text { All species } \\
\begin{array}{l}\log (x+1) \\
p>0.05\end{array}\end{array}$}} & \multirow{3}{*}{\multicolumn{3}{|c|}{$\begin{array}{l}\text { Sand-associated } \\
\text { invertevores } \\
\text { Log }(x+1) \\
p>0.05\end{array}$}} & \multirow{3}{*}{\multicolumn{3}{|c|}{$\begin{array}{l}\text { Plant-associated } \\
\text { invertevores } \\
\text { Log }(x+1) \\
\text { p }<0.05\end{array}$}} & \multirow{3}{*}{\multicolumn{3}{|c|}{$\begin{array}{l}\text { Omnivores } \\
\begin{array}{c}\log (x+1) \\
p>0.05\end{array}\end{array}$}} & \multirow{3}{*}{\multicolumn{3}{|c|}{$\begin{array}{l}\text { Zooplanktivores } \\
\qquad \begin{array}{c}\log (x+1) \\
p>0.05\end{array}\end{array}$}} \\
\hline \multirow{3}{*}{$\begin{array}{l}\text { Transformation: } \\
\text { Cochran's test: }\end{array}$} & & & & & & & & & & & & & & & \\
\hline & & & & & & & & & & & & & & & \\
\hline & MS & $F$ & $\mathrm{p}$ & $\mathrm{MS}^{\mathrm{T}}$ & $F$ & $\mathrm{p}$ & MS & $F$ & $\mathrm{p}$ & $\mathrm{MS}$ & $F$ & $\mathrm{p}$ & $\mathrm{MS}$ & $F$ & $\mathrm{p}$ \\
\hline Habitat & 6.0 & & & 7.3 & & & 2.1 & & & 0.76 & & & 9.7 & & \\
\hline Beach (Habitat) & 2.4 & 1.8 & 0.219 & 1.2 & 1.0 & 0.443 & 0.53 & 2.8 & 0.101 & 0.62 & 1.2 & 0.393 & 4.7 & 2.0 & 0.184 \\
\hline Season & 5.0 & & & 1.5 & & & 0.04 & & & 3.7 & & & 9.8 & & \\
\hline Block (Season) & 0.19 & 0.14 & 0.873 & 1.4 & 1.2 & 0.341 & 0.20 & 1.05 & 0.393 & 0.46 & 0.87 & 0.454 & 0.65 & 0.28 & 0.762 \\
\hline Habitat $\times$ Season & 0.04 & & & 0.60 & & & 0.01 & & & 1.9 & & & 2.0 & & \\
\hline Habitat × Block (Season) & 0.27 & 0.20 & 0.823 & 3.0 & 2.6 & 0.135 & 0.28 & 1.5 & 0.286 & 0.59 & 1.1 & 0.376 & 0.82 & 0.36 & 0.711 \\
\hline Beach (Habitat) $\times$ Season & 0.92 & 0.68 & 0.627 & 0.12 & 0.10 & 0.977 & 0.11 & 0.57 & 0.693 & 1.4 & 2.6 & 0.119 & 3.9 & 1.7 & 0.241 \\
\hline $\begin{array}{r}\text { Beach (Habitat) } \times \text { Block } \\
(\text { Season })\end{array}$ & 1.3 & 2.8 & 0.010 & 1.2 & 6.5 & 0.001 & 0.19 & 2.6 & 0.014 & 0.53 & 2.1 & 0.048 & 2.3 & 2.5 & 0.017 \\
\hline Residual & 0.49 & & & 0.18 & & & 0.07 & & & 0.25 & & & 0.91 & & \\
\hline
\end{tabular}

or temporal trends in numbers of individuals were obscured by significant variation at finer spatial and temporal scales.

\section{Biomasses}

Overall, total biomass was less dominated by zooplanktivores (Table 3). The numerically dominant species were also less important in terms of their biomass (Table 3). Perhaps because of this, patterns in the biomasses of fish were less subject to fine-scale variability than were patterns in the numbers of individuals (Table 5). Only zooplanktivore biomass showed significant interaction between among-beach spatial variation and between-block temporal variation. However, between-block variability was still important enough in most cases $(p<0.25)$ to preclude pooling, so tests of the significance of between-habitat and betweenseason differences were not possible. (We note that the mean squares were highest for the habitat factor in all analyses.) Beach identity was an important source of variation in biomass for sand-associated invertevores (Table 5). Challenger yielded the highest overall biomasses for most groups (Fig. 4).

\section{Associations with depth and drift}

Depth and amount of drift varied among beaches, with no consistent patterns between beaches with and without seagrass. Overall, beaches at Buchanan and

Table 5. Results of ANOVA on biomasses of all species combined and each of the feeding guilds. No exact $F$-test was possible for habitat, season, or the habitat $\times$ season interaction. Bold type indicates terms for which $\mathrm{p}<0.05$

\begin{tabular}{|c|c|c|c|c|c|c|c|c|c|c|c|c|c|c|c|}
\hline \multirow{4}{*}{$\begin{array}{l}\text { Guild } \\
\text { Transformation: } \\
\text { Cochran's test: }\end{array}$} & \multicolumn{3}{|c|}{ All species } & \multirow{3}{*}{\multicolumn{3}{|c|}{$\begin{array}{l}\text { Sand-associated } \\
\text { invertevores } \\
\text { Log }(x+1) \\
\text { p > } 0.05\end{array}$}} & \multirow{3}{*}{\multicolumn{3}{|c|}{$\begin{array}{c}\text { Plant-associated } \\
\text { invertevores } \\
\log (x+1) \\
\text { p }<0.05\end{array}$}} & \multirow{3}{*}{\multicolumn{3}{|c|}{$\begin{array}{l}\text { Omnivores } \\
\begin{array}{c}\log (x+1) \\
p>0.05\end{array}\end{array}$}} & \multirow{3}{*}{\multicolumn{3}{|c|}{$\begin{array}{l}\text { Zooplanktivores } \\
\qquad \begin{array}{c}\log (x+1) \\
p>0.05\end{array}\end{array}$}} \\
\hline & \multirow{2}{*}{\multicolumn{3}{|c|}{$\begin{array}{c}\text { Untransformed } \\
p>0.05\end{array}$}} & & & & & & & & & & & & \\
\hline & & & & & & & & & & & & & & & \\
\hline & MS & $F$ & $\mathrm{p}$ & MS & $F$ & $\mathrm{p}$ & MS & $F$ & $\mathrm{p}$ & MS & $F$ & $\mathrm{p}$ & $\mathrm{MS}$ & $F$ & $\mathrm{p}$ \\
\hline Habitat & 49123914 & & & 8.7 & & & 8.5 & & & 2.7 & & & 18.2 & & \\
\hline Beach (Habitat) & 19477749 & 2.4 & 0.127 & 5.1 & 6.1 & 0.014 & 2.3 & 2.9 & 0.089 & 1.8 & 1.9 & 0.196 & 3.9 & 1.4 & 0.315 \\
\hline Season & 4285662 & & & 5.9 & & & 1.4 & & & 0.06 & & & 0.29 & & \\
\hline Block (Season) & 927881 & 0.12 & 0.889 & 2.0 & 2.4 & 0.151 & 0.27 & 0.34 & 0.718 & 0.79 & 0.85 & 0.461 & 6.1 & 2.2 & 0.172 \\
\hline Habitat $\times$ Season & 2339364 & & & 8.4 & & & 1.3 & & & 1.6 & & & 0.79 & & \\
\hline $\begin{array}{r}\text { Habitat } \times \text { Block } \\
\text { (Season) }\end{array}$ & 8975236 & 1.1 & 0.365 & 3.5 & 4.2 & 0.054 & 2.1 & 2.6 & 0.128 & 1.3 & 1.5 & 0.278 & 0.97 & 0.34 & 0.715 \\
\hline $\begin{array}{l}\text { Beach }(\text { Habitat }) \times \\
\quad \text { Season }\end{array}$ & 4483334 & 0.57 & 0.691 & 0.64 & 0.76 & 0.576 & 0.65 & 0.80 & 0.553 & 0.46 & 0.49 & 0.738 & 2.6 & 0.96 & 0.476 \\
\hline $\begin{array}{r}\text { Beach (Habitat) } \times \\
\text { Block (Season) }\end{array}$ & 7842471 & 1.6 & 0.128 & 0.84 & 1.2 & 0.290 & 0.80 & 1.7 & 0.104 & 0.92 & 0.94 & 0.484 & 2.7 & 2.2 & 0.032 \\
\hline Residual & 4781246 & & & 0.67 & & & 0.46 & & & 0.97 & & & 1.2 & & \\
\hline
\end{tabular}



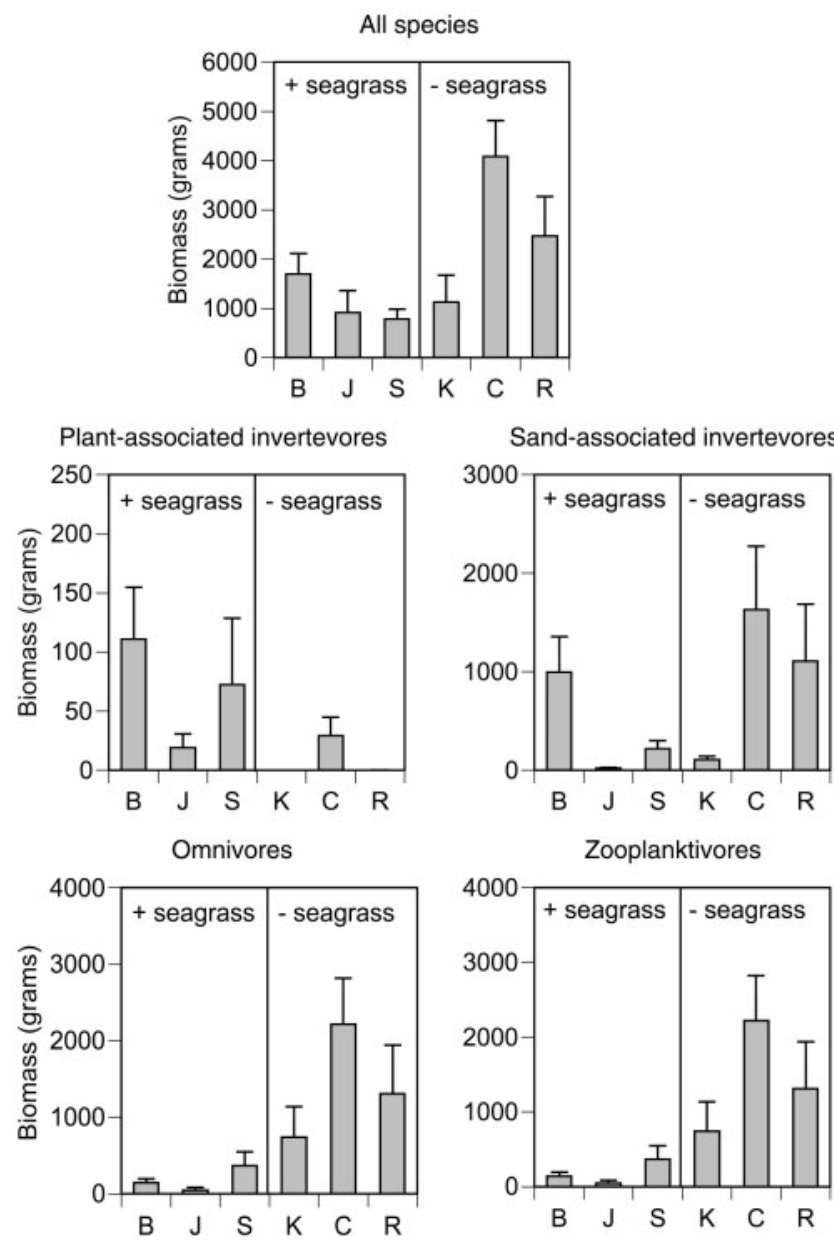

Fig. 4. Mean biomasses $(+\mathrm{SE}, \mathrm{n}=16)$ of all species and each of the feeding guilds at each beach within each habitat. See Fig. 1 for beach abbreviations

Sulphur (with seagrass) and Rockingham (without seagrass) tended to be shallower (generally 0.5 to $1.5 \mathrm{~m}$ ) than beaches at Kwinana (without seagrass) and Jervoise (with seagrass), where depths generally reached 2 to $3 \mathrm{~m}$. Depths at Challenger (without seagrass) were intermediate (1.5 to $2 \mathrm{~m}$ ).

The amount of drift captured in the hauls varied among beaches, but not consistently according to whether there was seagrass adjacent. Beaches at Kwinana, Rockingham and Jervoise tended to have little or no drift, Buchanan regularly had large quantities, and Sulphur and Challenger had variable amounts.

The numbers of species of all groups showed significant associations with depth (Table 6) and tended to be higher in catches from shallow water. Numbers of individuals showed no significant association with depth (Table 6). Biomasses of sand-associated invertevores and omnivores showed significant associations with depth (Table 6): biomasses of sand-associated invertevores tended to be higher in shallow water, while biomasses of omnivores tended to be higher in deeper water.

The number of species, number of individuals and biomass of plant-associated species were positively associated with drift (Table 6). Similarly, the number of omnivore species was higher in catches with large amounts of drift (Table 6).

\section{DISCUSSION}

Generally, the numbers of species, numbers of individuals and biomasses showed few clear patterns related to the presence or absence of seagrass. The numbers of species varied among beaches and was strongly influenced by depth, and for some guilds, the amount of drift present, regardless of whether beaches had adjacent seagrass. Broad trends in numbers of individuals were obscured by large fluctuations among catches: more fish were caught at beaches with no adjacent seagrass (numbers were dominated by zooplanktivores and Sillago vittata, a sand-associated invertevore), but these differences were obscured by high variability among beaches and among times. High variation is common in studies attempting to detect the effects of stressors on fish assemblages and can make detection of trends difficult (Rose 2000). Estimates of biomass were less subject to short-term temporal variation and for some guilds, beach identity was important.

Despite the high variability among catches, NPMANOVA did show significant differences in the composition of fish assemblages between habitats when data from different times were analyzed separately. For example, results suggested that sandassociated invertevores varied between habitats in May-June. Within this guild, patterns were complex: while catches of some species were higher at beaches without seagrass (e.g. Sillago vittata), catches of others were higher at beaches with seagrass (e.g. S. schomburgkii).

There are several possible reasons why these differences occur. Some species shelter in seagrass beds, but forage over adjacent unvegetated habitats (Summerson \& Peterson 1984). Another possibility is indirect effects via trophic pathways (Heck et al. 1995, Asmus \& Asmus 2000). Shaw \& Jenkins (1992) found that the greenback flounder Rhombosolea tapirina fed primarily on harpacticoid copepods and suggested that high densities of these invertebrates were supported by seagrass detritus. In Cockburn Sound, the presence of sediment organic matter from seagrass decay may be important, but knowledge of the linking processes is 
Table 6. Results of multiple regressions of the number of species, number of individuals and biomasses against water depth and amount of drift. Bold type indicates terms for which $\mathrm{p}<0.05$

\begin{tabular}{|c|c|c|c|c|c|c|}
\hline \multirow[t]{2}{*}{ Dependent } & \multirow[t]{2}{*}{$\mathrm{r}^{2}$} & \multirow[t]{2}{*}{$\mathrm{p}$} & \multicolumn{2}{|c|}{ Depth } & \multicolumn{2}{|c|}{ Drift macrophyte } \\
\hline & & & $\begin{array}{l}\text { Regression } \\
\text { coefficient } b\end{array}$ & $\mathrm{p}$ & $\begin{array}{c}\text { Regression } \\
\text { coefficient } b\end{array}$ & $\mathrm{p}$ \\
\hline \multicolumn{7}{|l|}{ Number of species } \\
\hline All species & 0.084 & 0.027 & -1.139 & 0.008 & -0.188 & 0.373 \\
\hline Sand-associated invertevores & 0.076 & 0.038 & -0.799 & 0.016 & 0.045 & 0.785 \\
\hline Plant-associated invertevores & 0.327 & $<0.001$ & -0.368 & 0.049 & 0.494 & $<0.001$ \\
\hline Omnivores & 0.151 & 0.001 & -0.587 & 0.030 & 0.335 & 0.014 \\
\hline Zooplanktivores & 0.058 & 0.083 & -0.418 & 0.033 & -0.114 & 0.246 \\
\hline \multicolumn{7}{|l|}{ Number of individuals } \\
\hline All species & 0.019 & 0.454 & 70.095 & 0.873 & -258.93 & 0.243 \\
\hline Sand-associated invertevores & 0.025 & 0.349 & -15.972 & 0.574 & -20.354 & 0.153 \\
\hline Plant-associated invertevores & 0.242 & $<0.001$ & 0.821 & 0.279 & 1.944 & $<0.001$ \\
\hline Omnivores & 0.013 & 0.566 & 6.744 & 0.422 & -2.052 & 0.627 \\
\hline Zooplanktivores & 0.016 & 0.507 & 78.468 & 0.858 & -238.41 & 0.283 \\
\hline \multicolumn{7}{|l|}{ Biomass } \\
\hline All species & 0.002 & 0.908 & -116.25 & 0.774 & 51.516 & 0.801 \\
\hline Sand-associated invertevores & 0.063 & 0.069 & -520.62 & 0.029 & 27.271 & 0.818 \\
\hline Plant-associated invertevores & 0.082 & 0.030 & 2.623 & 0.913 & 31.932 & 0.010 \\
\hline Omnivores & 0.085 & 0.026 & 410.09 & 0.008 & 79.396 & 0.296 \\
\hline Zooplanktivores & 0.004 & 0.834 & -4.714 & 0.987 & -88.516 & 0.557 \\
\hline
\end{tabular}

poor for even relatively well-studied species. Probably the best-studied group in southwestern Australia is the Sillaginidae. Four species were captured during this study. The 2 most abundant, Sillago vittata and $S$. schomburgkii, showed different distribution patterns, yet both prefer bare sand habitats (Hyndes et al. 1996) and feed on copepods, amphipods and polychaetes (Hyndes et al. 1997). Little information exists on whether preferred invertebrates utilize seagrass detritus. More information is needed before the role of seagrass detritus as a potential food source can be better understood.

Other influences may have confounded simple answers. One influence in this study was the distribution of drift. We attempted to explore the influence of drift using ordinal estimates. More species, more individuals and higher biomasses of plant-associated invertevores were captured in hauls where drift was abundant. Similarly, more species of omnivores were captured in hauls where drift was abundant. These 2 guilds were not numerically abundant, comprising only $3.1 \%$ of all individuals, but comprised $19.6 \%$ of total biomass. These results suggest that a distinct assemblage of fishes may be associated with drift in Cockburn Sound. Association of fishes with drifting macrophytes has been reported elsewhere (Kulczycki et al. 1981, Robertson \& Lenanton 1984, Kingsford \& Choat 1985, Langtry \& Jacoby 1996). Many of the fishes associated with drift in our study were juveniles (unpubl. length data) and this suggests that drift, including seagrass, might provide an important nursery habitat.

Indirect effects of seagrass loss on faunal assemblages that rely on drift are difficult to predict, because we know relatively little about the numerous linking processes. The relatively small amount of research that has been done suggests that areas with drift macrophytes (seagrasses and macroalgae) may support distinctive fish assemblages and higher numbers of fish relative to unvegetated habitats (Kulczycki et al. 1981, Lenanton et al. 1982, Robertson \& Lenanton 1984, Ochieng \& Erftemeijer 1999). Fish may use drift as shelter from predators (Lenanton et al. 1982) and may feed on invertebrates associated with drift (Lenanton et al. 1982, Robertson \& Lenanton 1984).

Local conditions are probably important in determining the amount of drift seagrass received. The dispersal of drift seagrass will be influenced by factors such as direction and intensity of currents, buoyancy of the seagrass and proximity of the source to the destination. These influences may ameliorate the effects of seagrass loss from areas immediately adjacent. If the supply of detritus is maintained from distant sources, even populations susceptible to change may remain unaffected. The amount of drift we encountered was not strictly linked to the proximity of seagrass and it also varied through time. These variations influenced the types of fishes we captured at different places and times during this study. 
Drift macroalgae can be important to fish off sandy beaches (Lenanton et al. 1982), but in Cockburn Sound, there is relatively little rocky substrata, so macroalgae detritus (other than algae epiphytic on seagrass) may not be very important. However, at Challenger, which has small areas of rocky reef nearby (see Fig. 1), drift included both seagrass and macroalgae.

\section{Inferences about the effects of seagrass loss}

This study provided limited evidence for differences related to presence or absence of seagrass. There were some differences in species composition, but many of the analyses were dominated by fine-scale spatial and temporal variation. Part of the variation in catches can be explained by spatial and temporal variation in the distribution of drift: drift seagrass was associated with a distinct assemblage of fishes, but was not restricted to beaches immediately adjacent to seagrass beds.

An additional constraint to drawing inferences about the influence of seagrass is the lack of interspersion. Ideally, beaches with and without adjacent seagrass should be spatially interspersed, but the configuration of seagrass in Cockburn Sound prevented this. The alternative explanation that the differences we found are purely spatial cannot be completely discounted.

Despite this, some inferences can be drawn about the likely impacts of seagrass loss on sandy beach habitats. From our results, it seems likely that some species in this assemblage were adversely affected by the reduced supply of drift that must have followed the loss of $>3000$ ha of seagrass in Cockburn Sound. Our study was designed to test for spatial patterns, not to explicitly quantify processes influencing detrital pathways. However, clear spatial patterns were not present. Their absence suggests that the effects of seagrass loss on faunal assemblages, supported by trophic pathways based on seagrass detritus, are complex. Further studies will be needed to ascertain the level of influence of each of the factors. We suggest that a fruitful avenue of inquiry could be a more explicit study of the magnitude of drift export from seagrass beds, the distance and direction of export, and the eventual fate of the drift.

Acknowledgements. We gratefully acknowledge the help of the many people who assisted with the fieldwork, with particular thanks to S. Langtry. P. Horwitz provided advice and encouragement during the study. S. Ayvazian, B. Hutchins, P. Last, M. Hewitt and D. Jones helped identify specimens we could not. M. Aylward provided the map of Cockburn Sound. G. Hyndes, P. Francour and A. J. Smit provided valuable suggestions on how to improve the manuscript.

\section{LITERATURE CITED}

Anderson MJ (2001) A new method for non-parametric multivariate analysis of variance. Aust Ecol 26:32-46

Anderson MJ, Legendre P (1999) An empirical comparison of permutation methods for tests of partial regression coefficients in a linear model. J Stat Comput Simulation 62: 271-303

Asmus H, Asmus R (2000) Material exchange and food web of seagrass beds in the Sylt-Romo Bight: how significant are community changes at the ecosystem level? Helgol Mar Res 54:137-150

Ayvazian SG, Hyndes GA (1995) Surf-zone fish assemblages in south-western Australia: do adjacent nearshore habitats and the warm Leeuwin Current influence the characteristics of the fish fauna? Mar Biol 122:527-536

Belbin L (1991) Semi-strong hybrid scaling, a new ordination algorithm. J Veg Sci 2:491-496

Bellan-Santini D, Picard J (1984) Consequences de la regression des herbiers de posidonies pour le benthos animal des autres milieux Mediterraneens. In: Boudouresque CF, Jeudy De Grissac A, Olivier J (eds) International workshop on Posidonia oceanica beds, Vol 1. GIS Posidonie Publ, France, p 423-429

Cambridge ML, McComb AJ (1984) The loss of seagrass in Cockburn Sound, Western Australia. I. The time course and magnitude of seagrass decline in relation to industrial development. Aquat Bot 20:229-243

Dybdahl RE (1979) Technical report on fish productivity: an assessment of the marine faunal resources of Cockburn Sound. Department of Conservation and Environment Report No. 4. Department of Conservation and Environment Report, Perth

Edgar GJ, Shaw C (1995) The production and trophic ecology of shallow-water fish assemblages in southern Australia II. Diets of fishes and trophic relationships between fishes and benthos at Western Port, Victoria. J Exp Mar Biol Ecol 194:83-106

Estes JA, Smith NS, Palmisano JF (1978) Sea otter predation and community organization in the western Aleutian Islands, Alaska. Ecology 59:822-833

Gray JS (1997) Marine biodiversity: patterns, threats and conservation needs. Biodivers Conserv 6:153-175

Heck KL Jr, Able KW, Roman CT, Fahay MP (1995) Composition, abundance, biomass, and production of macrofauna in a New England estuary: comparisons among eelgrass meadows and other nursery habitats. Estuaries 18: 379-389

Hyndes GA, Potter IC, Lenanton RCJ (1996) Habitat partitioning by whiting species (Sillaginidae) in coastal waters. Environ Biol Fishes 45:21-40

Hyndes GA, Platell ME, Potter IC (1997) Relationships between diet and body size, mouth morphology, habitat and movements of 6 sillaginid species in coastal waters: implications for resource partitioning. Mar Biol 128:585-598

Jackson JBC (2001) What was natural in the coastal oceans? Proc Natl Acad Sci USA 98:5411-5418

Jenkins GP, May HMA, Wheatley MJ, Holloway MG (1997) Comparison of fish assemblages associated with seagrass and associated unvegetated habitats of Port Phillip Bay and Corner Inlet, Victoria, Australia, with emphasis on commercial species. Estuar Coast Shelf Sci 44:569-588

Kendrick GA, Aylward MJ, Hegge BJ, Cambridge ML, Hillman K, Wyllie A, Lord DA (2002) Changes in seagrass coverage in Cockburn Sound, Western Australia between 1967 and 1999. Aquat Bot 73:75-87

Kingsford MJ, Choat JH (1985) The fauna associated with 
drift algae captured with a plankton-mesh purse seine net. Limnol Oceanogr 30:618-630

Kulczycki GR, Virnstein RW, Nelson WG (1981) The relationship between fish abundance and algal biomass in a seagrass-drift algae community. Estuar Coast Shelf Sci 12: 341-347

Langtry SK, Jacoby CA (1996) Fish and decapod crustaceans inhabiting drifting algae in Jervis Bay, New South Wales. Aust J Ecol 21:264-271

Lenanton RCJ, Robertson AI, Hansen JA (1982) Nearshore accumulations of detached macrophytes as nursery areas for fish. Mar Ecol Prog Ser 9:51-57

McArdle BH, Anderson MJ (2001) Fitting multivariate models to community data: a comment on distance-based redundancy analysis. Ecology 82:290-297

Nagelkerken I, Kleijnen S, Klop T, Van den Brand RACJ, de la Moriniere EC, Van der Velde G (2001) Dependence of Caribbean reef fishes on mangroves and seagrass beds as nursery habitats: a comparison of fish faunas between bays with and without mangroves/seagrass beds. Mar Ecol Prog Ser 214:225-235

Ochieng CA, Erftemeijer PLA (1999) Accumulation of seagrass beach cast along the Kenyan coast: a quantitative assessment. Aquat Bot 65:221-238

Polis GA, Anderson WB, Holt RD (1997) Toward an integration of landscape and food web ecology: the dynamics of spatially subsidized food webs. Annu Rev Ecol Syst 28: 289-316

Robertson AI, Lenanton RCJ (1984) Fish community structure and food chain dynamics in the surf-zone of sandy beaches: the role of detached macrophyte detritus. J Exp Mar Biol Ecol 84:265-283

Editorial responsibility: Kenneth Heck (Contributing Editor), Dauphin Island, Alabama, USA
Rose KA (2000) Why are quantitative relationships between environmental quality and fish populations so elusive? Ecol Appl 10:367-386

Scott JK, Dybdahl R, Wood WF (1986) The ecology of Posidonia seagrass fish communities in Cockburn Sound, Western Australia. Technical Series 11. Department of Conservation and Environment, Perth

Shaw M, Jenkins GP (1992) Spatial variation in feeding, prey distribution and food limitation of juvenile flounder Rhombosolea tapirina Günther. J Exp Mar Biol Ecol 165: $1-21$

Shepard SA, McComb AJ, Bulthius DA, Neverauskas V, Steffensen DA, West R (1989) Decline of seagrasses. In: Larkum AWD, McComb AJ, Shepherd SA (eds) Biology of seagrasses: a treatise on seagrasses with special reference to the Australian region. Elsevier Science Publishers, Amsterdam, p 346-393

Short F, Wyllie-Echeverria S (1996) Natural and humaninduced disturbance of seagrass. Environ Conserv 23:17-27

Suchanek TH (1994) Temperate coastal marine communities: biodiversity and threats. Am Zool 34:100-114

Summerson HC, Peterson CH (1984) Role of predation in organizing benthic communities of a temperate-zone seagrass bed. Mar Ecol Prog Ser 15:63-77

Vanderklift MA (1996) Fish assemblages off sandy beaches in Cockburn Sound. MSc thesis, Edith Cowan University, Joondalup

Vanderklift MA, Jacoby CA, Horwitz P (1998) Comparison of catches taken in dual-mesh beach seines of 2 different lengths. Mar Freshw Res 49:513-516

Zar JH (1996) Biostatistical analysis, 3rd edn. Prentice-Hall, Upper Saddle River, NJ

Submitted: November 21, 2001; Accepted: September 6, 2002 Proofs received from author(s): January 6, 2003 